in the learning of serially presented nonsense strings in the German language. But it suggests, as well, that time and nonlinguistic structure (through subjective organizational schemes of various kinds) can be traded off for linguistic structure on the basis of economy, efficiency, or need.

\section{REFERENCES}

BRYK, J. A. The influence of syntax in rote verbal learning. Unpublished doctoral dissertation, St. Louis University, 1968.

BRYK, J. A., \& O'CONNELL, D. C. Immediate recall as a function of grammatical structure and mode of presentation. Psychonomic Science, 1967, 8, 437-438.

DENNER, B. Perceptual processing of syntactically structured and unstructured strings. Perceptual \& Motor Skills, 1966, 23, 1310.

DUNNE, M. M. The effect of syntactic structure on learning. Journal of Verbal Learning \& Verbal Behavior, 1968, 7, 458-463.

EPSTEIN, W. The influence of syntactical structure on learning. American Journal of Psychology, 1961, 74, 80-85.

EPSTEIN, W. A further study of the influence of syntactical structure on learning. American Joumal of Psychology, 1962, 75, 121-126.

EPSTEIN, W., \& ARLINSKY, M. The interaction of syntactical structure and learning instructions. Psychonomic Science, 1965, 3, 59-60.

FORSTER, K. I. The effect of syntactic structure on nonordered recalt. Journal of Verbal Learning \& Verbal Behavior, 1966, 5, 292-297.

HÖRMANN, H. Psychologie der Sprache. Berlin: Springer-Verlag, 1967.

JENSEN, A. R., \& ROHWER, JR., W. D. Syntactical mediation of serial and paired-associate learning as a function of age. Child Development, 1965, 36, 601-608.

LEVIN, J. R., \& ROHWER, JR., W. D. Verbal organization and the facilitation of serial learning. Journal of Educational Psychology, $1968,59,186-190$.

NEISSER, U. Cognitive psychology. New York: Appleton-Century-Crofts, 1967.

O'CONNELL, D. C. Nonsense strings, words, and sentences: Some cross-linguistic comparisons. Psychologische Forschung, in press.

O'CONNEIL, D. C., STUBBS, C. L., \& THEBY, M. A. Facilitation of recall by structure in serially presented nonsense strings. Psychonomic Science, 1968, 12, 263-264.

O'CONNELL, D. C. TURNER, E. A., \& ONUSKA, L. A. Intonation, grammatical structure, and contextual association in immediate recall. Journal of Verbal Learning \& Verbal Behavior, 1968, 7, 110-116.

OSGOOD, C. E. Psycholinguistics. In S. Koch (Ed.), Psychology: A study of a science. Vol. 4. New York: McGraw-Hill, 1963. Pp. 244-316.

OSGOOD, C. E. Toward a wedding of insufficiences. In T. R. Dixon \& D. L. Horton (Eds.), Verbal behavior and general behavior theory. Englewood Cliffs, N. J Prentice-Hall, 1968. Pp. 495-518.

ROSENBERG, $S$. The influence of grammatical and associative habits on verbal learning. $\ln S$. Rosenberg (Ed.), Directions in psycholinguistics. New York: Macmillan, 1965. Pp. 121-145.

SALZINGER, K., \& ECKERMAN. C. Grammar and the recall of chains of verbal responses. Journal of Verbal Learning \& Verbal Behavior.
$1967,6,232-239$.

SIMPSON, W. E. Effects of approximation to sentence word-order and grammatical class upon the serial learning of word lists. Joumal of Verbal Learning \& Verbal Behavior, 1965 4, $510-514$.

WALES, R. J. Problems of repetition in verbal learning. Paper at the British Psychological Society, London, England, 1964.
NOTE

1. The research reported in the following article has been supported by the Alexander von Humboldt lioundation of Bad Godesberg, Germany, and by the Psychological Institute of the Free University of Berlin. It was made possible by the generosity of St. Louis University in granting the first author a leave of absence for purposes of research.

\title{
Choice reaction time as a function of intersensory anticipation
}

\section{CAROLYN DONALDSON and ALFRED E. HALL, 1 College of Wooster, Wooster, Ohio 44691}

Choice $R T$ of 10 college students was compared under two conditions. One condition was a single-choice condition in which, I sec after a warning signal, one of a pair of stimulus lights was flashed and $S$ was required to move a right-hand lever in the appropriate direction. In the double-choice condition, a second stimulus (high or low tone) followed the first stimulus by $1 / 2 \mathrm{sec}$, and $S$ was, in addition, required to respond to it by moving a left-hand lever in the appropriate direction. Average $R T$ to the light in the single-choice condition was significantly shorter $(p<.01)$ than the RT to the same stimulus in the double condition. These data provide additional evidence that present behavior is affected by S's expectation of the immediate future.

The effect of anticipation upon reaction time (RT) has been the object of several studies. Poulton (1950) found that simple RT was about $25 \mathrm{msec}$ longer when the $S$ was required to initiate a complex pattern-tracing task than when he had to make a simple response (break an electrical contact). Poulton interpreted these and other findings to mean that present performance is affected by the S's awareness of future events or requirements. Inhibition of simple RT was also found in a study by Helson \& Steger (1962), in which Ss were required to respond to a stimulus light that was itself followed 10 to $180 \mathrm{msec}$ later, on half the trials, by another stimulus light. However, other experiments (Lappin \& Eriksen, 1964 Koplin, Fox, \& Dozier, 1966) have failed to replicate this increase in simple RT.

Gottsdanker, Broadbent, \& Van Sant (1963) found inhibition of RT to occur in a choice-RT situation. They measured choice RT for six adults under two conditions. One was a single-choice condition in which a warning light flashed, and $1 \mathrm{sec}$ later, one of two previously designated lights flashed. The $S$ responded by moving a lever in the direction of the signal light that flashed. The other condition was a double-choice situation that was like the above condition, except that $1 / 2$ sec after the first stimulus lamp was presented, one of another pair of stimulus lamps was flashed. The results showed that, for all Ss, the mean RT for the single-choice condition was significantly shorter than was the same response in the double-choice condition.

The design of the present study was similar to that of Gottsdanker et al (1963), except that stimuli of different modalities were employed. The main purpose of the experiment was to study the effects of a second (auditory) stimulus on the RT to a first (visual) stimulus.

\section{SUBJECTS AND MATERIALS}

The Ss used were 10 undergraduate, introductory psychology students at the College of Wooster ( 5 male and 5 female). Five additional students served as pilot Ss. All Ss were right-handed.

The visual stimuli were two yellow $1 / 4-W$ bulbs. The auditory stimuli were two easily discriminable tones: one approximately $300 \mathrm{~Hz}$ and the other about $800 \mathrm{~Hz}$.

The display and controls consisted of a $3 \times 2 \frac{1}{2} \mathrm{ft}$ flat-black board. It was supported on a table at the longer ends by two 2 in. $x 4$ in. $x 3 \mathrm{ft}$ wooden blocks. In the center of the board were four $1 / 4-W$ bulbs placed in a 1 -in. square. Centered and $1 / 2$ in. above these was another $1 / 4-\mathrm{W}$ bulb (white) used as the warning light. Three inches above this bulb was a $4 \times 4 \times 4$ in. metal speaker that presented the two tones. The pair of stimulus bulbs on the right side of the center display was yellow, and that on the left was red. (The latter pair was not used in this experìment.) Centered between the two lamps on the right and 1 in. farther to the right was a 
steel lever covered with plastic. It could be moved in the direction of either of the two right-hand bulbs (i.e., toward $S$ or away from him). A similar lever was placed midway between the left-hand pair of bulbs and 1 in. to the left of them. It was to be moved away from the $S$ in response to the sound of the high tone $(800 \mathrm{~Hz})$ and toward him in response to the low tone $(300 \mathrm{~Hz})$.

The apparatus was housed in a $5 \times 6 \times 10 \mathrm{ft}$ high cubicle. The controls for presentation of stimuli and conditions were mounted on a metal box containing the wiring system attached to the display board. A $3 \times 2 \mathrm{ft}$ unpainted plywood board, fastened to the top side of the display board, prevented $\mathrm{S}$ from being able to see $\mathrm{E}$ or the control panel during experimentation.

Time intervals between trials, between the warning light and the first signal (visual), and between the first and the second signal (auditory), which were $20 \mathrm{sec}, 1 \mathrm{sec}$, and $1 / 2 \mathrm{sec}$, respectively, were controlled by three Hunter interval timers. The light flash of approximately $20 \mathrm{msec}$ and 20 -msec tone were produced by direct current through the wiring system.

Presentation of the visual stimulus started a Standard electric timer that was stopped when $\mathbf{S}$ moved the right-hand lever in the proper direction, away from or toward him, depending on which of the lamps flashed. Presentation of the auditory stimulus started a second Standard timer that was stopped by the movement of the left-hand lever in the appropriate direction. Times were recorded to the nearest 100th of a second.

\section{PROCEDURE}

In the single-choice condition, the $S$ was told that $1 \mathrm{sec}$ after the warning light flashed, one of the two lamps of the right-hand pair would flash. The $\mathrm{S}$ was instructed to respond by moving the right-hand response lever as quickly as possible, away from him if the farther light flashed and toward him if the nearer one flashed. Due to the complex wiring needed to counterbalance stimulus positions, only lights of the right-hand pair could be used as stimuli.

In the double-choice condition, $S$ was informed that $1 \mathrm{sec}$ after the warning lamp flashed, one of the two right-hand signals would flash as in the above condition. He was to respond in the same manner. Then, $1 / 2 \mathrm{sec}$ after the onset of the first signal, a tone was to be presented. He was required to respond to the high tone by moving the left-hand lever away from him and to respond to the low tone by moving this lever toward him.
Each S attended a 20-min session on each of 3 consecutive days. The 1st day was a practice session in which $S$ was familiarized with the apparatus and stimuli, heard standard instructions, and received 15 practice trials under each condition. The condition presented in the first test session was randomly determined: Half of the Ss were given the single-choice condition first, and half of the Ss were given the double-choice condition. Before each session, the instructions were reviewed, and $S$ was given 5 warm-up trials of the condition to be tested in that period; these trials were immediately followed by 40 test trials. If $S$ made an error, the data for that trial were discarded, and the trial was repeated at the end of the series. No information was given to $S$ about his performance.

\section{RESULTS}

The mean RT to each stimulus (i.e., top light, bottom light, high tone, and low tone) was computed for each $S$ under each condition. The means for the lights are presented in Table 1. For every $S$ except one, the mean RT to a light in the single-choice condition was shorter than the mean RT to the same light in the double-choice condition. The average RT in the double-choice condition was $.0265 \mathrm{sec}$ shorter than that in the single-choice condition $(.3790 \mathrm{sec}$ vs $.3525 \mathrm{sec}$ ).

A 2 by 2 by 10 triple-classification analysis of variance for repeated measures (McNemar, 1962, pp. 318-329) was computed to compare Ss' mean RT to the light in the single-choice condition with their mean RT to the same stimulus in the double condition. The $F$ ratio between single and double conditions was significant $(F=19.64, \mathrm{df}=1 / 9, \mathrm{p}<.01)$, but the other $F$ tests of interest were not: top light vs bottom light $(F=3.63$, $\mathrm{df}=1 / 9, \mathrm{p}>.05)$ and interaction between condition and position of stimulus $(F=.002, \mathrm{df}=1 / 9, \mathrm{p}>.05) .^{2}$

\section{DISCUSSION}

In the Gottsdanker et al study (1963), in which Ss were required to respond to a second visual stimulus (which was presented $1 / 2 \mathrm{sec}$ after the first stimulus), inhibition of RT to a visual first stimulus was found. In the present study, which was modeled after the Gottsdanker et al study (1963), S's response to a visual stimulus was found to be inhibited by anticipation of a stimulus of a different modality (audition), which also required a response. These findings suggest that a unified intersensory complex was formed in the more complex, double-choice condition
Table 1

Mean Choice RTs to Light for Each S Under Single-Choice and Double-Choice Conditions

\begin{tabular}{|c|c|c|c|c|}
\hline \multirow[b]{2}{*}{$\mathbf{S}$} & \multicolumn{2}{|c|}{ Single-Choice } & \multicolumn{2}{|c|}{ Double-Choice } \\
\hline & $\begin{array}{c}\text { Top } \\
\text { Light }\end{array}$ & $\begin{array}{c}\text { Bottom } \\
\text { Light }\end{array}$ & $\begin{array}{l}\text { Top } \\
\text { Light }\end{array}$ & $\begin{array}{c}\text { Bottom } \\
\text { Light }\end{array}$ \\
\hline 1 & 33.30 & 31.40 & 36.70 & 38.85 \\
\hline 2 & 35.00 & 30,20 & 53.35 & 53.85 \\
\hline 3 & 28.65 & 28.00 & 33.15 & 33.95 \\
\hline 4 & 32.70 & 31.35 & 35.95 & 33.30 \\
\hline 5 & 37.25 & 37.90 & 42.95 & 35.25 \\
\hline 6 & 33.10 & 35.15 & 42.00 & 37.85 \\
\hline 7 & 30.85 & 30.40 & 37.55 & 39.55 \\
\hline 8 & 29.05 & 26.95 & 35.45 & 34.15 \\
\hline 9 & 30.50 & 32.60 & 44.85 & 42.85 \\
\hline 10 & 32.95 & 30.90 & 40.15 & 43.65 \\
\hline $\mathbf{M}$ & 32.34 & 31.48 & 40.21 & 39.32 \\
\hline
\end{tabular}

Note $-N=20$ for each entry. Numbers represent hundredths of a second.

that affected the behavior of the Ss. In other words, it appears that a S's responses to a series of intersensory stimuli in a certain situation are not direct reactions to separately analyzed elements but are each a part of a total configuration resulting from $S$ 's perceptual classification of the expected series of stimuli into a unified complex. Poulton's thesis (1950) that present behavior is affected by the individual's expectations of the immediate future has been further supported by the findings of this experiment.

\section{REFERENCES}

GOTTSDANKER, R., BROADBENT, L., \& VAN SANT, C. Reaction time to single and to first signals. Journal of Experimental Psychology, 1963, 66, 163-167.

HELSON, H., \& STEGER, J. A. On the inhibitory effects of a second stimulus following the primary stimulus to react. Journal of Experimental Psychology, 1962, 64, 201-205.

KOPLIN, J. H., FOX, R., \& DOZIER, F, A failure to replicate the inhibitory effects of a second stimulus following the primary stimulus to react. Journal of Experimental Psychology, 1966, 72, 914-916.

LAPPIN, J. S., \& ERIKSEN, C. W. Inhibition of a simple visual reaction time by a second stimulus: A fajlure to replicate. Psychonomic Science, 1964, 1, 293-294.

McNEMAR, Q. Psychological statistics. (3rd ed.) New York: Wiley, 1962.

POULTON, E. C. Perceptual anticipation and reaction time. Quarterly Joumal of Experimental Psychology, 1950, 2, 99-112. NOTES

1. This experiment was carried out as a junior independentstudy project; the second author served as advisor.

2. The difference between the mean RTs to the visual and auditory stimuli was also analyzed, and all sources of variance tested were insignificant $(\mathrm{p}>.05)$. These data are not reported here since the difference between the first and second RT is confounded with hand preference and position of stimuli, and the design does not include adequate controls for making valid comparisons. No use was intended of these data. 